\title{
A STUDY ON INVESTMENT PREFERENCES AMONG THE HOUSE HOLDS IN TIRUNELVELI DISTRICT
}

\author{
Dr. R. Thanga Selvan \\ Assistant Professor, Department of Commerce, \\ Sindhi College of Arts and Science, \\ Chennai, Tamilnadu, India
}

\begin{abstract}
Investment preferences of household investors at various instruments along with spotingneth sources of various preferences and consequences. The culture of investment pattern has been revamped a different circumstances due to micro and macro environmental factors. It is virtually reengineered among the investors before and after economic liberalizations of India. These aspects are thoroughly analyses through selected reviews and aims to address the gap of various investment influences in investors evaluation patterns of choosing an opt investment.
\end{abstract}

Key words: House Holds, Tirunelveli, economic

Cite this Article: R. Thanga Selvan, A Study on Investment Preferences among the House Holds in Tirunelveli District, International Journal of Management, 11(12), 2020, pp 2374-2377.

http://iaeme.com/Home/issue/IJM?Volume=11\&Issue=12

\section{INTRODUCTION}

Investment preference indicates the selecting of a particular mode of investment by the individual. This can be classified into physical savings and financial savings. Physical savings include the investment made in land and building, gold and silver and other valuables. On the other hand, financial savings include saving in the form of bank and post office deposits, provident fund savings, saving through share market and mutual fund, saving in chit funds, etc.

\section{REVIEW OF LITERATURE}

Kohli (2010) indicated that the share of financial investments of the household sector in securities (shares, debentures, public sector bonds and units of Unit Trust of India and other mutual funds and government securities) is estimated to have gone down from 22.9 percent in 1991- 92 to 3.9 per cent in 1997 - 98, which increased marginally to 4.3 per cent in $1998-99$. 
It is also found that only 2.8 per cent of investment of all households was in securities (1.4 per cent in equity shares, 1.3 per cent in mutual funds and 0.4 per cent in debentures), while the remaining 97 per cent in non - securities, indicating low priority of investor for securities. Despite the expansion of the securities market, a very small percentage of household investments is channelized into the securities market.

The study made by Gus and diary (2010) noted that the investors who choose traditional products like gold, land chits furies and other products indicated move satisfaction from their investment, since the rate of return from such products is more or less given or known to them. Only a few households suggested that they could not get the return they expected from their investment. But such disappointment is is almost nil among those who have invested in gold.

Jain (2011) examined the preferences made by investors among various saving and investment products in Gujarat and found that there is a significant relationship between the level of education and the nature of products opted by investors, since those with less education opted for the traditional products like chit funds, private finance, gold and silver, while those with higher education opted for modern products like pension funds, mutual funds, Government investment bonds and also share market.

\section{OBJECTIVES}

- To analyze the investment preferences among the households in tirunelveli district

- To analyze the type of financial asset preferred, by the investors.

- To identify the factors and objectives of investing in financial assets.

\section{RESEARCH DESIGN}

The researcher has used multi - stage proportionate random sampling has used for this study.

\section{Sampling design:-}

The direct personal interview method will be adopted to collect the duties from sample responds.

\section{Sample size:-}

The data was collected from a sample of 100 respondents out of the total household in Tirunelveli district.

\section{Data collection:-}

The study is based on primary and secondary date the secondary data pertaining to the total investment the household sector investments their components have been collected from the annual reports of the RBI and other published documents. In the case of primary data information pertaining to the investment pattern level of income expenditure and other factors are gathered through a questionnaire. 
Table 1 The demographic and carrier profile of the respondents.

\begin{tabular}{|c|c|c|}
\hline DESCRIPTION & NO OF RESPONDENTS & PERCENTAGE \\
\hline \multicolumn{3}{|c|}{ RESPONDENTS AGE:- } \\
\hline Up to 30 & 14 & $14 \%$ \\
\hline $31-40$ & 24 & $24 \%$ \\
\hline $41-50$ & 30 & $30 \%$ \\
\hline Above 50 & 32 & $32 \%$ \\
\hline \multicolumn{3}{|l|}{ GENDER } \\
\hline Male & 70 & $70 \%$ \\
\hline Female & 30 & $30 \%$ \\
\hline \multicolumn{3}{|c|}{ MARITAL STATUS:- } \\
\hline Married & 72 & $72 \%$ \\
\hline Unmarried & 28 & $28 \%$ \\
\hline \multicolumn{3}{|c|}{ EDUCATIONAL LEVELS } \\
\hline Up to Higher Secondary & 10 & $10 \%$ \\
\hline Under Graduate & 37 & $37 \%$ \\
\hline Post Graduated & 30 & $30 \%$ \\
\hline Professional Degree & 23 & $23 \%$ \\
\hline \multicolumn{3}{|c|}{ MONTHLY INCOME } \\
\hline Up to Rs. 20,000 & 15 & $15 \%$ \\
\hline Rs. $21,000-30,000$ & 24 & $24 \%$ \\
\hline Rs. $31,000-50,000$ & 36 & $36 \%$ \\
\hline Above Rs 50,000 & 25 & $25 \%$ \\
\hline \multicolumn{3}{|c|}{ OCCUPATION: } \\
\hline Government Employee & 25 & $25 \%$ \\
\hline Self Employed & 11 & $11 \%$ \\
\hline Business & 14 & $14 \%$ \\
\hline Private employee & 22 & $22 \%$ \\
\hline Private Professional & 28 & $28 \%$ \\
\hline \multicolumn{3}{|c|}{ MONTHLY SAVINGS:- } \\
\hline Up to $10 \%$ & 22 & $22 \%$ \\
\hline $11-15 \%$ & 38 & $38 \%$ \\
\hline $16-20 \%$ & 27 & $27 \%$ \\
\hline Above $20 \%$ & 13 & $13 \%$ \\
\hline
\end{tabular}

Source: Computed from field survey.

The table - 1 show the demographic and carrier profile of the respondents. It was inferred that $32 \%$ of the respondents belong to the age group of Above 50 years. $70 \%$ are Male, $72 \%$ are married , 37\% hold under graduate degree 36 belong to the income category of $31,000-$ $50,000,45 \%$ belong to the private professionals and $38 \%$ belong to the $11.15 \%$ of monthly savings.

Table 2 Modes of Investments among the Respondents

\begin{tabular}{|l|c|c|}
\hline \multirow{2}{*}{$\begin{array}{c}\text { MODES OF } \\
\text { INVESTMENTS }\end{array}$} & \multicolumn{2}{c|}{$\begin{array}{c}\text { RESPONDENTS } \\
\text { PERCENTAGE }\end{array}$} \\
\cline { 2 - 3 } & YES & NO \\
\hline Bank & $85.5 \%$ & $14.5 \%$ \\
\hline Post Office & $41.6 \%$ & $58.4 \%$ \\
\hline Chit Funds & $42.7 \%$ & $57.3 \%$ \\
\hline Private Finance & $13.3 \%$ & $86.7 \%$ \\
\hline Land \& Other Properties & $65.5 \%$ & $34.5 \%$ \\
\hline Gold \& Silver & $78.4 \%$ & $21.6 \%$ \\
\hline
\end{tabular}




\begin{tabular}{|l|c|c|}
\hline Govt. Investments Bonds & $41.0 \%$ & $59.0 \%$ \\
\hline Life Insurance & $76.9 \%$ & $23.1 \%$ \\
\hline Pension Funds & $16.7 \%$ & $83.3 \%$ \\
\hline Mutual funds & $24.9 \%$ & $75.1 \%$ \\
\hline Bank Fixed Deposits & $74.3 \%$ & $25.7 \%$ \\
\hline Share Market & $10.4 \%$ & $89.6 \%$ \\
\hline
\end{tabular}

Source: Computed from field survey.

It is observed from the above table that out of 100 respondents $85.5 \%$ of the respondents investment through bank, $78.4 \%$ of the respondents have invested in gold and silver, $76.9 \%$ of the respondents investment through life insurance followed by bank fixed deposits $74.3 \%$, land and other properties $65.5 \%$, pension funds $16.7 \%$, share market $10.4 \%$ respectively mode of investments among the households in Tirunelveli district.

Table 3 Rate of Return from the Various Investment Instrument

\begin{tabular}{|l|c|c|c|c|}
\hline \multicolumn{1}{|c|}{ RATE OF RETURN } & NO OPTION & UPTO 10\% & $\mathbf{1 1 - 2 0 \%}$ & $\mathbf{2 1 - 4 0 \%}$ \\
\hline Bank saving deposits & $14.5 \%$ & $85.5 \%$ & NILL & NILL \\
\hline Post Office & $58.4 \%$ & $41.6 \%$ & NILL & NILL \\
\hline Chit Funds & $56.9 \%$ & $17.6 \%$ & $25.5 \%$ & NILL \\
\hline Provident Fund & $20.4 \%$ & $79.6 \%$ & NILL & NILL \\
\hline Land & NILL & $26.1 \%$ & $45.7 \%$ & $28.2 \%$ \\
\hline Gold \& Silver & $22.0 \%$ & $16.7 \%$ & $61.4 \%$ & NILL \\
\hline Govt. Investments Bonds & $59.0 \%$ & $41.0 \%$ & NILL & NILL \\
\hline Life Insurance & $23.1 \%$ & $76.9 \%$ & NILL & NILL \\
\hline Pension Funds & $83.3 \%$ & $16.7 \%$ & NILL & NILL \\
\hline Mutual funds & $75.1 \%$ & $15.9 \%$ & $46.0 \%$ & NILL \\
\hline Bank Fixed Deposits & $25.7 \%$ & $74.3 \%$ & NILL & NILL \\
\hline Share Market & $89.6 \%$ & $6.9 \%$ & $3.5 \%$ & NILL \\
\hline
\end{tabular}

Source: Computed from field survey.

The table - 3 shows that $85.5 \%$ respondents have invested in bank saving deposits and they get the rate of return at Upto $10 \%$, while $45.7 \%$ respondents invest in Land obtain the rate of return at $11-20 \%$. At the same time $79.6 \%$ respondents in Life insurance, $74.3 \%$ respondents in Bank fixed deposits get their rate of return at Upto $10 \%$ are unable to predict the investment in Tirunelveli district.

\section{CONCLUSION}

This study brings out the fact that through many modes of investments are available to the investors, their dependence is particularly wider in modes like land, gold and silver, bank and post office savings and also provident fund and government saving instrument. Thus, the investors are mostly risk averse, since they want to depend on secured modes of investments. It is clearly shown that the percentage of preference for modes like chit funds, mutual fund and the share market is quite negligible for different reasons. Moreover, the rate of return from the most of the investments which are safer is less, while the return from land and gold and silver is comparatively high and hence, the preference for them is also higher among the investors.

\section{REFERENCES}

[1] Kohil, S., (2010), "Financial Liberalization Index for India", International Review of Applied Financial Issues and Economics, Vol 34,No. 3,pp.76-82.

[2] Jain, R., (2011),"A study on the Investment preferences among the Households in Gujarat", ICFAI Journal of finance, April, pp. 23-26. 